\section{A Liquefaction Plant for Natural Gas}

THE city of Cleveland, on the south shore of Lake Erie, has a population of more than 1,200,000. For domestic purposes and many industries, natural gas is supplied by the East Ohio Gas Co., the gas being brought to Cleveland through four pipe-lines from Hastings, West Virginia, about 150 miles distant. In the early part of each year, short spells of extremely cold weather are experienced, and during these spells there is a great increase in gas consumption. To meet these exceptional demands a liquefaction and storage plant has been erected possessing many interesting features. A description of the plant and a diagram of the processes involved are given in the Engineer of May 22. The natural gas is first freed from moisture, carbon dioxide and nitrogen, and then by means of refrigerators the gas is liquefied and its temperature reduced to $-258^{\circ} \mathrm{F}$., at which temperature it is stored in three insulated spherical tanks under a pressure of $10 \mathrm{lb}$. A tank consists of an inner sphere of stainless steel $54 \mathrm{ft}$. in diameter, and an outer sphere of mild steel $60 \mathrm{ft}$. in diameter. The intervening space is filled with cork through which dried gases are passed to absorb moisture. The total amount of liquid gas stored in the three tanks is equal to the amount of free gas which could be contained in fifty ordinary gas holders each having a capacity of $3,000,000 \mathrm{cub}$. ft.

\section{Institute of Physics}

THE annual report of the Board of the Institute of Physics which was adopted at the general meeting held on May 28 records the continued growth in numbers and activities of the Institute. One of the features of the year was the formation of the Industrial Radiology Group-the first subject Group to be formed-under the auspices of the Institute. This step has already been followed by the formation of an Electronics Group. The following were elected to take office on October 1, 1942: President, Sir Lawrence Bragg; Vice-Presidents, Dr. W. Makower and Mr. T. Smith ; Honorary Treasurer, Major C. E. S. Phillips ; Honorary Secretary, Prof. J. A. Crowther ; Ordinary Members of the Board, Prof. J. Chadwick, Prof. J. D. Cockeroft, Mr. D. C. Gall and Mr. E. B. Wedmore.

\section{Newton Tercentenary Celebrations}

THE Royal Society will, if circumstances permit, celebrate, at its anniversary meeting on November 30 , the tercentenary of the birth of Sir Isaac Newton. The programme, which will be a modest one owing to the War, is to include three lectures, to be delivered in the Society's apartments at Burlington House, Piccadilly, on "Newton and the Science of his Age", by Prof. E. N. da C. Andrade, Quain professor of physies in the University of London; "Newton as an Experimenter" (with demonstrations), by Lord Rayleigh, emeritus professor of physics in the Imperial College of Science and Technology; and "Newton and the Science of To-day", by Sir James Jeans, professor of astronomy in the Royal Institution of Great Britain.

\section{Storage of National Wheatmeal}

A REPORT on the problem of the storage qualities of National wheatmeal has been published by the Research Association of British Flour-Millers in Milling of May 23. Storage trials were carried out over a period of a year and included not only laboratory experiments but also tests under commercial conditions in mills, bakeries and buffer depots. Moisture content is the most important factor determining storage life: thus at $14,14 \frac{1}{2}$ and $15 \frac{1}{2}$ per cent moisture contents, provided the storage conditions are good and a sound wheat grist is used, the wheatmeals will keep in good condition for 9 months, 4-6 months and 2 months respectively. Temperature is a further factor, and whereas at $60^{\circ} \mathrm{F}$. a wheatmeal of $15 \frac{1}{2}$ per cent moisture remained in good condition for 11 weeks, at $77^{\circ} \mathrm{F}$. it kept only for 3-4 weeks. An additional point of importance revealed by the experiments is that National wheat meal is more prone to insect infestation than white flour.

\section{Silver Leaf Disease}

Sruver leaf is one of the most serious diseases with which fruit growers have to contend, and the Advisory Leaflet No. 246 issued by the Ministry of Agriculture should do much to clear up misunderstandings on the nature of the disease and thereby improve the methods of control. Stereum purpureum is a parasitic fungus which attacks the living tissues of the wood by means of wound penetration. It does not occur in the foliage, and the silvering of the leaves is merely a secondary effect of the attack. Discoloration and eventual death of the infected woody parts of the tree occur, followed by the development of fruiting bodies, by means of which the disease is spread. Illustrations of these fructifications are given, for their recognition on dying trees, old stumps or logs is important if adequate control of the disease is to to be obtained.

The silvered leaves do not constitute a source from which the disease can spread. Natural recovery is always a possibility in a slightly affected tree, and removal of all silvered branches in the early stages may prevent an extension of the trouble. Branches that have begun to die back, however, must be cut out and burnt early in the summer and no stumps or roots of a dead tree left in the ground. Every effort should be made to prevent and protect natural wounds on the trees, as it is at such surfaces that the parasite gains an entry. Many kinds of fruit trees may be attacked by this disease, but plums are particularly susceptible, though the variety, or the stock on which the variety is grafted, may influence the susceptibility to some extent. A list of the more commonly attacked varieties of plum and apple is given.

\section{Carnegie United Kingdom Trust}

THE twenty-eighth annual report of the Carnegie United Kingdom Trust (Dumfermline: The Trust) covers the year 1941, and for reasons of economy omits the accounts from the general distribution although they can be obtained on application. Considerations which govern the grant policy of the trustees are detailed in an appendix. The two main policies upon which the Trust is now engaged, operating on a year-to-year basis, are youth service and music. In regard to the former, grants have been offered to local voluntary bodies in aid of capital expenditure on the equipment of clubs for young people, including both the initial equipment of new clubs and the provision of additional equip. ment for existing ones. Contributions have also been made to the headquarters administration of the National Associations of Boys' Clubs, Girls' Clubs 